\title{
Effects of Perceived Attributes, Perceived Risk and Perceived Value on Usage of Online Retailing Services
}

\author{
Peter Misiani Mwencha (Corresponding Author) \\ School of Business, Kenyatta University \\ P.O. Box 53555-00200 Nairobi, Kenya \\ E-mail: mwencha@hotmail.com
}

Stephen Makau Muathe

School of Business, Kenyatta University

P.O. Box 43844 - 00100 Nairobi, Kenya

E-mail: muathesm@yahoo.com

John Kuria Thuo

School of Business, Gretsa University

P.O. Box 3-01000, Thika, Kenya

E-mail: thuokuria@yahoo.com

Received: March 2, 2014

Accepted: March 28, 2014

Published: April 1, 2014

doi:10.5296/jmr.v6i2.5224

URL: http://dx.doi.org/10.5296/jmr.v6i2.5224

\begin{abstract}
This study sought to establish the effect of perceived attributes, perceived risk and perceived value on usage of online retailing services in Nairobi, Kenya. It employed a descriptive, correlational, survey design whereby a sample of 391 respondents who are registered users of 6 online retailing services in Nairobi, Kenya was selected using multi-stage sampling methods. Primary data was collected using an electronic questionnaire instrument, while secondary data was collected via a review of relevant records and documents. The data was analyzed using both descriptive as well as inferential statistics. Results show that all three perceptual factors have a significant effect on the usage of online retailing services.
\end{abstract}

Keywords: Online retailing usage, Customer perceptions, Consumer decision making, E-commerce 


\section{Introduction}

The commercial use of the Internet has grown tremendously over the last two decades, characterized by a proliferation of various online-based electronic commerce (e-commerce) services. One of these services is online retailing, which has been variously described as internet retailing, e-retailing, or e-tailing (Anderson, 2000), as part of interactive home shopping (Alba, Lynch, Weitz, \& Janisqewski, 1997), and by the broader terms electronic commerce (Daniel \& Klimis, 1999) and e-commerce (Boscheck, 1998).

Due to its huge popularity, online retailing has had a significant impact on several market segments such as travel, consumer electronics, hobby goods, and media goods across the globe (Weltevrenden \& Boschma, 2008). Consequently, online retailing has developed to become an established marketing channel in its own right within the consumer marketplace (Doherty \& Ellis-Chadwick, 2010).

Kenya is showing strong online retailing growth potential, as it was the fastest growing Internet market in Africa in 2011 (yStats.com, 2012) with its internet population rising by about $19 \%$ to stand at 14.032 million users in 2012 from 12.5 million in 2011 (Communications Commission of Kenya (CCK), 2012). This remarkable growth in internet usage has been characterized by a surge in e-commerce activities, with several applications and services being introduced into the market at great cost. However, while the adoption of these services is generally high, the conversion rate of initial users to long-term users is very low (Magutu, Mwangi, Nyaoga, Ondimu, Kagu, Mutai, Kilonzo, \& Nthenya, 2011).

In the long run, this low usage of online retailing services poses a problem for service providers since low/ineffective usage by consumers after the initial adoption may incur undesirable costs of maintaining the loss-making service. Continued loss-making may eventually lead to closure of the service, resulting in waste of effort to develop the system (Cooper \& Zmud, 1990; Bhattacherjee, 2001a).

Given that past studies have established that the success of online retailers depends more heavily on the continued use of their services to purchase an increasingly wide range of products than on initial adoption (Parthasarathy \& Bhattacherjee, 1998; Shih \& Venkatesh, 2004; Limayem, Hirt \& Cheung, 2007), this study therefore seeks to establish the predictors of continued usage of online retailing firms by consumers in Kenya.

Customer perceptions have been shown to have significant effect on continued use of online retailing services (Parthasarathy \& Bhattacherjee, 1998; Bhattacherjee, 2001b; Venkatesh, Morris, Davis \& Davis, 2003). Consequently, the customer perception construct serves as the independent variable in this study. It is composed of three constructs (perceived attributes, perceived risk and perceived value) identified in literature as playing an antecedent role in online retailing usage. This study therefore sought to determine what effect perceived attributes, perceived risk and perceived value have on usage of online retailing services in Nairobi, Kenya.

\subsection{Theoretical Orientation}

This study is underpinned by four theories commonly used in consumer technology adoption research. These are (i) Innovation Diffusion Theory, (ii) Perceived Risk Theory (iii) Theory 
of Consumption Values and (iv) Uses and Gratifications Theory. Amongst these, the Uses and Gratifications theory is the dominant theoretical lens used in this study to explain continued online retailing usage behavior.

\subsubsection{Uses and Gratifications Theory}

The Uses and Gratifications Theory (U\&G) is a classical media use theory that is concerned with how people use media (Roy, 2008). The theory is based on a psychological communication perspective that focuses on individual use and choice by asserting that different people can use the same mass medium for very different purposes (Severin \& Tankard, 1997).

$\mathrm{U} \& \mathrm{G}$ is largely intended to identify the psychological needs that motivate the use of a particular medium to gratify those needs (Ko, Cho \& Roberts, 2005). U\&G provides a user-level perspective rather than a mass-exposure perspective (Rayburn, 1996). As a result, the theory has been useful in explaining consumer behavior and concerns in the context of traditional media ranging from radio to television, cable TV, TV remote controls, and now the Internet. For this reason, various researchers (Chen \& Wells, 1999; Korgaonkar and Wolin, 1999; Kaye \& Johnson, 2001; Luo, 2002; Ko et al., 2005; Huang, 2008) have applied U\&G in the context of the Internet.

U\&G theory is particularly useful in explaining continuing use (McGuire, 1974). According to the theory, whereas initial use may be a result of accidental exposure or curiosity, continuing use assumes there are underlying motivations driving repeated use. In other words, if users are not receiving certain rewards or gratifications from using a certain medium, they would stop using that medium (Joines, Scherer \& Scheufele, 2003).

For e-commerce use, specific motivations have been identified in two categories: utilitarian and hedonic (Kau, Tang, \& Ghose 2003; Peng 2007; Zhou, Dai, \& Zhang, 2007). Online retailing users with utilitarian motivations are concerned with searching and purchasing products for efficient and timely transaction in order to achieve their goals. Convenience, freedom, privacy, control, accessibility, and availability of information are found to be factors for utilitarian use of the ecommerce. On the other hand, hedonic motivations refer to the entertainment and enjoyment aspects of e-commerce use (Choi and Jahng, 2009). These e-commerce specific motivations extracted from $U \& G$ research could be essential predictors of e-commerce activities. (Joines et al., 2003).

\subsubsection{Innovation Diffusion Theory}

Grounded in sociology, the Innovation Diffusion Theory (IDT) by Rogers (1962; 1995; 2003) is one of the first models to be employed in technology adoption research. It has been used since the 1960 s to study a variety of innovations, ranging from agricultural tools to organizational innovation (Tornatzky \& Klein, 1982). IDT describes how innovations (ideas, practices and technology) are spread into a social system network resulting in institutionalization of the innovation by incorporating it in routine practice/ continued usage (Murray, 2009). Using this approach, Internet shopping is regarded as an innovation, which like other innovations takes time to spread through the social system (Alba, Lynch, Weitz \& 
Janisqewski, 1997; Verhoef \& Langerak, 2001).

The IDT focuses on the utility of an innovation - conceptualized as its perceived characteristics (attributes) - and posits that the rate of adoption is partially determined by the perceived attributes (or characteristics) of the innovation, and proposes several attributes potentially important across diverse innovation adoption domains. According to Rogers (1962; 1995; 2003), these perceived attributes (or core constructs) of this model include relative advantage, compatibility, complexity, trialability and observability.

These attributes were later refined by Moore and Benbasat (1991) in their perceived characteristics of using an innovation (PCI) model for the IS context to study individual technology acceptance into relative advantage, compatibility, ease of use (instead of complexity), image, result demonstrability and visibility (instead of observability), and voluntariness of use. Another related model is the technology adoption model (TAM), whose two constructs, perceived usefulness and perceived ease of use, are quite similar to the IDT constructs - perceived relative advantage and perceived complexity (Davis, 1989; Al-Gahtani, 2001). Consequently, in this study, the perceived attributes construct (perceived usefulness, perceived compatibility and perceived ease of use) is drawn from the IDT, the related PCI model and TAM.

Empirical MIS studies based on the IDT have largely supported the predictive power of the theory (Fichman \& Kemerer, 1999; Chircu \& Kaufmann, 2000). The theory was applied in the online shopping context by Verhoef and Langerak (2001) who explored the impacts of relative advantage, compatibility, and complexity on e-shopping in their study of Dutch households. They found that consumers' perception of relative advantage and compatibility positively influenced their intention to adopt online grocery shopping. Also, results obtained by Hansen (2005) suggest that perceived complexity, perceived compatibility, and perceived relative advantage highly influence consumers' adoption of online grocery buying.

However, the theory has its limitations, the major one being that while it explains the formation of a favorable attitude toward a particular innovation, it does not provide further analysis of the attitude evolving into the adoption behavior (Chen, Gillenson \& Sherrell, 2002).

\subsubsection{Perceived Risk Theory}

The Perceived Risk Theory was first introduced by Bauer (1960) in studying consumer behavior. According to this theory, consumers perceive risk because they face uncertainty and potentially undesirable consequences as a result of purchase or usage of products/services. This means that the more risk consumers perceive, the less likely they will purchase/use a product or service (Bhatnagar, Misra \& Rao, 2000). The perceived risk construct in this study is derived from the perceived risk theory and adapted to the online retailing context.

The core constructs of the theory have been decomposed by researchers into several perceived risk dimensions. For instance, Cunningham (1967) conceptualized six dimensions of perceived risk: performance, financial, opportunity/time, safety, social, and psychological risk, while Bhatnagar et al. (2000) argued that two types of risk exist when buying over the 
internet; product risk and financial risk. These risks are thought to be present in every choice situation but in varying degrees, depending upon the particular nature of the decision (Taylor, 1974). Moreover, different individuals have different levels of risk tolerance or aversion (Bhatnagar et al., 2000).

Perceived risk has been applied in various studies of the consumer technology use context. For instance, an early study of telephone shopping by Cox and Rich (1964) found that consumers perceive higher risks in new innovative channel. In the e-commerce context, perceived risk has been applied in studies such as internet banking adoption (Tan \& Teo, 2000), usage of e-commerce services (Liebermann \& Stashevsky, 2002) continued usage of internet banking (El-Kasheir, Ashour \& Yacout, 2009), online consumers' purchasing behavior (Zhang, Tan, Xu \& Tan, 2012) amongst others.

\subsubsection{Theory of Consumption Value}

The theory of consumption values (TCV) is a consumer behavior theory that was developed by Sheth, Newman and Gross (1991a; 1991b). Over the years, TCV has evolved into a popular marketing theory and has been widely applied in various contexts, including IS. The theory focuses on explaining why consumers choose to use or not to use a specific product or service, arguing that consumer decisions are made based on perceived value.

The TCV has five core constructs which are conceptualized as five different types of values (Functional value, Social value, Epistemic value, and Emotional value, and Conditional value) that underlie consumer choice behavior. A particular choice may be determined by one value or influenced by several values (Sheth et al., 1991a; 1991b). In this study, the perceived value construct is drawn from the TCV by Sheth et al. (1991a; 1991b) and adapted to the online retailing context.

Kalafatis, Ledden and Mathioudakis (2011) re-specified three fundamental propositions that underpin the TCV: (1) consumer choice is a function of multiple consumption values; (2) the values make differential contributions in the choice situation, and (3) the values are independent of each other. Thus, all or any of the consumption values can influence a decision and can contribute additively and incrementally to choice; consumers weight the values differently in specific buying situations, and are usually willing to trade-off one value in order to obtain more of another.

TCV's strong point is its analytical strength, which helps practitioners to understand consumer decision making. This enables them to develop practical strategies that address real market conditions (Gimpel, 2011). TCV has been used in several IS studies on technology adoption decisions (Kim, Lee \& Kim, 2008).

On the other hand, TCV's main limitation is due to the fact that it applies only in cases of individual, voluntary and rational or systematic decision situations (Sheth et al., 1991a, 1991b); therefore, it cannot be used to predict the behaviour of two or more individuals and is thus restricted to individual end-user/consumer acceptance contexts.

\section{Study Variables}


The study is composed of four key variables: i) perceived attributes, ii) perceived risk, iii) perceived value and iv) usage. These variables are drawn from extant consumer behavior and technology adoption literature regarding the hypothesized relationships between them. These variables are discussed in the following sections.

\subsection{Usage of Online Retailing Services}

System usage is considered as dependent variable in various empirical studies (Bokhari, 2005). Due to its complexity and importance, a variety of measures have been developed and used to assess system usage in the IS field (see for example, Doll \& Torkzadeh, 1998). The use of a system depends on the users' evaluation of that system (Bokhari, 2005). Given the empirical support for the impact of continued usage on the success of an IS/IT, finding the significant factors that affect users' post-adoption behavior (either to continue or to discontinue usage of an IT) is of importance (Hong, Thong \& Tam, 2006). Accordingly, research in IT continuance has examined different factors and/or processes that motivate continued usage or discontinuance of IT products or services, following their initial acceptance (Bhattacherjee \& Barfar, 2011).

It is important to note that as opposed to organizational IS usage, individuals use IS such as online retailing services not only for utilitarian purposes, but also for hedonic purposes (Monsuwé, Dellaert \& De Ruyter, 2004; Bridges \& Florsheim, 2008; Ozen \& Kodas, 2012). Therefore, the affective aspect of online shopping is just as important as the cognitive aspect in both adoption and post-adoption contexts and therefore needs to be taken into consideration when seeking to establish what affects the usage of online retailing services (Ozen \& Kodas, 2012).

\subsection{Customer Perceptions}

Customer perceptions have been shown to have significant effect on continued use of online retailing services (Parthasarathy \& Bhattacherjee, 1998; Bhattacherjee, 2001b; Venkatesh, Morris, Davis \& Davis, 2003). Consequently, the customer perception construct serves as the independent variable in this study. It is composed of three constructs (perceived attributes, perceived risk and perceived value) identified in literature as affecting online retailing usage.

\subsubsection{Perceived Attributes}

Perceived attributes (PA) have been found to influence consumer usage patterns vis-à-vis information and communications technology (ICT), whereby, users of ICTs would perceive the attributes of these innovations favorably, while non-users and rejecters perceive them unfavorably enough not to use them (Rugimbana \& Iversen, 1994). In this study, PA is a composite variable of three dimensions (perceived usefulness, perceived compatibility and perceived ease of use) drawn from Davis (1989), Rogers, (1995; 2003), and (Moore \& Benbasat, 1991).

In the IS context, prior studies reveal different usage outcomes based on the antecedent role of the PA. For instance, Parthasarathy and Bhattacherjee (1998) empirically established that perceived attributes such as usefulness and compatibility determine post-adoption usage of online services while Saeed and Abdinnour-Helm (2008) also showed that perceived IS 
usefulness is a good predictor of post-adoption usage. Moreover, Bhattacherjee's (2001b) study on antecedents of e-commerce service continuance demonstrated that perceived usefulness is a key determinant of customer's continued usage intention (CUI). However, a study by Smith, (2008) showed that perceived attributes do affect online retailing usage.

It can therefore be hypothesized as follows:

$\mathrm{H}_{0}$ : Perceived attributes do not have significant effect on usage of online retailing services.

\subsubsection{Perceived Risk}

Perceived risk (PR) is a subjective consumer behavior concept that relates to the uncertainty and consequences associated with a consumer's action. A perception of risk with regards to purchasing or using a product or service dissuades a consumer from taking further action in that regard (Sharma, Durand \& Gur-Arie, 1981; Bhatnagar, Misra \& Rao, 2000). In the online retailing context, the intangible nature of online transactions poses a risk for consumers, impeding further use of online purchasing services (Bhatnagar et al., 2000; Hansen, 2007).

Previous research on its antecedent role also suggests that perceived risk negatively impacts internet shopping (Liebermann \& Stashevsky, 2002). By and large, perceived risk is conceptualized as a multi-dimensional construct in several studies (Cox \& Rich, 1964; Jacoby \& Kaplan, 1972; Bettman, 1973; Bhatnagar et al., 2000, Zhang, Tan, Xu \& Tan, 2012). In this study, the perceived risk construct has three dimensions that have been derived from a review of relevant literature. These are i) financial risk (Jacoby \& Kaplan, 1972; Bettman, 1973, Bhatnagar et al., 2000), ii) performance risk (Jacoby \& Kaplan, 1972; Bettman, 1973) and iii) personal/privacy risks drawn from work by Jarvenpaa and Todd (1997).

It was therefore hypothesized that:

$\mathrm{H}_{0}$ : Perceived risk does not have a significant effect on usage of online retailing services.

\subsubsection{Perceived Value}

Perceived value (PV) is a broad and abstract concept that refers to the benefits ascribed to the purchase/use of a product or service. Perceived value is a complex construct that is multi-dimensional in nature (Sheth, Newman \& Gross, 1991; Sánchez-Fernández \& Iniesta-Bonillo, 2007). In this study has four dimensions drawn from relevant literature, namely i) monetary value, ii) convenience value, iii) social value and iv) emotional value.

Online customer value can be different from its offline counterpart. In online retailing settings, not only the product itself, but also the web store and the Internet channel contribute value to customers (Yunjie \& Shun, 2004). Previous research established that perceived customer value is a significant determinant of online transaction behavior (Chew, Shingi \& Ahmad, 2006) including repeat usage in the online service context (Yen, 2011). PV has also been established as one of the key factors affecting repeat usage in the online retailing context (Chen \& Dubinsky, 2003; Hu \& Chuang, 2012).

Therefore, the study hypothesized that:

$\mathrm{H}_{0}$ : Perceived value does not have significant effect on usage of online retailing services.

\section{Methodology}




\subsection{Research design}

This research adopted a cross-sectional, descriptive, correlational study design that sought to establish the effect of customer perceptions on the usage of online retailing services in Kenya. Descriptive, correlational studies entail the study phenomena without the ability to control or manipulate variables, and thus require the researcher to collect data and determine relationships without inferring causality (Swanson \& Holton, 2005).

\subsection{Sampling and data collection}

The respondents for this study were the 18,147 registered users drawn from six online retailing firms in Nairobi, Kenya that were accessible to the researcher. A sample of 391 respondents was selected using multi-stage sampling methods including purposive, stratified and simple random sampling. Primary data was collected using an electronic questionnaire composed of three different sections and which consisted of questions that were close-ended with ordered responses. The measures were adopted from previous studies and reworded to suit the context of the current study.

The online survey questionnaire was marked because the respondents were divided into two groups (active users and inactive users) depending on whether or not one was using online retailing service at the time of the survey. Depending on the current usage status, the respondent was presented with a corresponding survey questionnaire. A sample of the final questionnaire is shown in Appendix 1.

Secondary data was collected from a variety of industry sources including newsletters, directories and trade publications as well as from industry magazines.

\subsection{Data analysis}

Data was analyzed using both descriptive as well as inferential statistics. Descriptive statistics provide a summary of the characteristics of response data (Wilson, 2006). The descriptive statistics that were used in this study include frequency distribution (in terms of counts and percentages) as well as measures of central tendencies (mean) and dispersion (standard deviation).

Because of the dichotomous nature of the dependent variable (usage), logistic regression was used for inferential data analysis to establish effects of the predictor variables on the criterion variable. Logistic regression analysis is a non-linear method of modelling for dichotomous dependent variables (Liou, 2008). The logistic regression model that was used is expressed as:

$$
\operatorname{logit}[P(y=1)]=\mathrm{B}_{0}+B_{1} X_{1}+B_{2} X_{2}+B_{3} X_{3}+\varepsilon
$$

\section{Whereby:}

$\mathrm{y}=$ The dichotomous DV (usage of online retailing services) with 1 (active user) or 0 (inactive user). 


\section{1) Macrothink}

$\mathrm{y}=$ Estimated regression equation $=\mathrm{B}_{0}+\mathrm{B}_{1} \mathrm{X}_{1}+\mathrm{B}_{2} \mathrm{X}_{2}+\mathrm{B}_{3} \mathrm{X}_{3}+\varepsilon_{1}$

$\mathrm{P}=$ The conditional probability of an individual being classified as belonging to either of two outcome categories: 1 (active user) or 0 (inactive user).

$e=$ Exponential, the quantity $2.1828+$, the base for natural logarithms $\mathrm{X}_{1}, \mathrm{X}_{2}$, and $\mathrm{X}_{3}$

$\mathrm{B}_{0} \quad=$ Intercept Term

$\mathrm{B}_{1-3}=$ Logistic regression coefficients for predictor variables

$\mathrm{X}_{1} \quad=$ Perceived Attributes

$\mathrm{X}_{2} \quad=$ Perceived Risk

$\mathrm{X}_{3}=$ Perceived Value

$\varepsilon_{1}=$ Error Term

Statistical Package for Social Sciences (SPSS) software version 19 was used to conduct the data analysis. Data was presented in the form of tables and narratives.

\section{Results and Discussions}

The summary of the results is presented in two main sections: (1) demographic statistics and (2) test of hypotheses. Table 1, featuring demographic statistics, is analyzed first.

\subsection{Demographic statistics}

\subsubsection{Response rates}

From three hundred and ninety one (391) respondents who are registered as users of 6 online retailing services in Nairobi County, Kenya, two hundred and forty-two (242) were able to participate in the study by completing and returning the questionnaire. However, a number of these questionnaires (34) were poorly/improperly filled, while another 13 arrived too late, necessitating their exclusion from the study. Ultimately, the final respondents amounted to 195 , equivalent to a $49.87 \%$ response rate which was approximately $50 \%$. According to Rubin and Babbie (2011), a 50 percent response rate is considered adequate for reporting and analysis. This means that the response data was sufficient for analysis.

\subsubsection{Demographic characteristics}

This section shows the summarized responses regarding the demographic characteristics of the sample based on Section A of the questionnaire. 
Table 1. Demographic characteristics of the sample $(n=195)$

\begin{tabular}{|l|l|l|l|}
\hline Variable & Category & Frequency & Percentage \\
\hline Age & 18-23 Years & 23 & 11.8 \\
& 24-29 Years & 79 & 40.5 \\
& 30-35 Years & 67 & 34.4 \\
& 36-41 Years & 22 & 11.3 \\
& 42-47 Years & 4 & 2.1 \\
& 48 years and above & 0 & 0 \\
& Total & $\mathbf{1 9 5}$ & $\mathbf{1 0 0 . 0}$ \\
\hline Level of Education & High School Cert. & 1 & 0.5 \\
& Diploma & 26 & 13.3 \\
& Bachelor's Degree & 119 & 61.0 \\
& Masters Degree & 41 & 21.0 \\
& Doctorate & 6 & 3.1 \\
& Professional & 2 & 1.0 \\
& Other & 0 & 0 \\
& Total & $\mathbf{1 9 5}$ & $\mathbf{1 0 0}$ \\
\hline Monthly Income & Less than KSh24,999 & 28 & 14.4 \\
& KSh25,000 - 49,999 & 36 & 18.5 \\
& KSh50,000 - 74,999 & 42 & 21.5 \\
& KSh75,000 - 99,999 & 37 & 19.0 \\
& KSh100,000 - 124,999 & 26 & 13.3 \\
& KSh125,000 \& above & 26 & 13.3 \\
& Total & $\mathbf{1 9 5}$ & $\mathbf{1 0 0 . 0}$ \\
\hline
\end{tabular}

Source: Survey data (2013)

In terms of the age of the response group $(n=195)$, the majority of respondents $(40.5 \%)$ were between $24-29$ years while the minority $(2.1 \%)$ were between $42-47$ years of age. None of respondents were older than 48 years of age. When it comes to education, a majority of the respondents $(61 \%)$ have a Bachelor's degree, followed by $41(21 \%)$ who have a Master's degree and $26(13.3 \%)$ who have a diploma. Only $1(0.5 \%)$ had a high school certificate, while 2 had a professional qualifications. With regards to the monthly income of the respondents, the majority (21.5\%) earned between KSh 50,000 - 74,999 where as the minority - which was made up of two categories - had one group with a monthly income of between KSh 100,000 - 124,999 while the other group reportedly earned KShs 125,000 and above per month.

Taken as a whole, the demographic information showed that the respondents are predominantly young, relatively well educated and with relatively high levels of income. These findings concur with past studies regarding e-shoppers which established that the online shoppers are generally younger, with high level of income and a university education 
(Li, Kuo \& Russell, 1999; Vrechopoulos, Siomkos \& Doukidis, 2001; Dholakia \& Uusitalo, 2002).

\subsection{Test of hypotheses}

Regression analysis was performed on the data for purposes of establishing the effects of the independent variables on the DV. The relevant results are summarised in Table 4

Table 2. Results of Logistic Regression Analysis

\begin{tabular}{|l|c|c|c|c|}
\hline \multicolumn{1}{|c|}{ Variable } & $\boldsymbol{\beta}$ & $\mathbf{t}=\boldsymbol{\beta} / \mathbf{S . E}$ & Wald & P-Value \\
\hline Perceived Attributes & 5.431 & 2.858 & 8.167 & 0.004 \\
\hline Perceived Risk & -1.396 & -2.106 & 4.434 & 0.035 \\
\hline Perceived Value & 2.340 & 2.272 & 5.158 & 0.023 \\
\hline Customer Perceptions & 1.384 & 15.795 & - & 0.000 \\
\hline & & & & \\
\hline Observations (n) & & 195 & & \\
\hline Nagelkerke R Squared & & 0.967 & & \\
\hline Classification Rate & & $97.9 \%$ & & \\
\hline Note $*$ p $\leq 0.05$ & & & \\
\hline
\end{tabular}

Source: Survey data (2013)

For the logistic regression model summary, the coefficient of determination $\left(\mathrm{R}^{2}\right)$ was estimated using the Nagelkerke's $\mathrm{R}^{2}$, a goodness-of-fit measure recommended by Pallant (2007). Table 2 shows that it was 0.967 , indicating a very strong relationship between the IVs and the DV. This means that about $96.7 \%$ of the variation in the outcome variable is explained by the independent variables.

Additionally, the Wald statistic, was used to determine the "significance" of the contribution of each variable in the model, in line with Chan (2004), whereby, the higher the value, the more "important" it is. The relevant hypotheses tests that were conducted to assess the significance of the Wald statistic tested the null hypothesis at $95 \%$ confidence level wherein the acceptability level of the hypothesis test was $=0.05$, as recommended by Burns and Burns (2009). The relevant hypotheses tests are presented in the following sections.

\subsubsection{Hypothesis 1: Effect of Perceived Attributes on Usage of Online Retailing Services}

$\mathrm{H}_{0}$ : Perceived attributes do not have significant effect on usage of online retailing

As revealed in Table 2, the null hypothesis which proposes that perceived attributes has no statistically significant effect on the usage of online retailing services was rejected since $\beta \neq 0$ 
and $p$-value $=0.004$. This is consistent with past research by Adams, Nelson and Todd (1992), which empirically established perceived attributes such as usefulness and ease-of-use are important determinants of system use as well as by Parthasarathy and Bhattacherjee (1998) which established that the perceived attributes of an online service such as usefulness and compatibility determine usage behavior. Similarly, Bhattacherjee's (2001) empirical study of the antecedents of e-commerce service continued usage demonstrated that perceived usefulness is a key determinant of customer's continued usage intention (CUI). This can be interpreted that usage depends on cognitive beliefs (i.e. perceptions) about attributes of online retailing services.

\subsubsection{Hypothesis 2: Effect of perceived risk on usage of online retailing services}

$\mathrm{H}_{0}$ : Perceived risk does not have significant effect on usage of online retailing services

The research findings depicted in Table 2 show that for perceived risk, $\beta=-1.396$ and $p$-value $=0.035$. Hence, the null hypothesis for $\mathrm{H} 2$ is rejected since $\beta \neq 0$ and $\mathrm{p}$-value $<=0.05$. However, the study's findings show that perceived risk has a negative effect on usage. The result concurs with the findings of previous studies (Jarvenpaa \& Tractinsky, 1999; Bhatnagar et al., 2000; Lee, Park, \& Ahn, 2000; Forsythe, Chuanlan, Shannon \& Gardner, 2006; Barnes, Bauer, Neumann \& Huber, 2007) that perceived risk is negatively associated with online shopping. It also parallels a more recent study by Liu and Forsythe (2010) who argued that risk is often a barrier to online transactions. This simply means that the greater the perceived risk, the less likely consumer are to use online retailing services in the future.

\subsubsection{Hypothesis 3: Effect of perceived value on usage of online retailing services}

$\mathrm{H}_{0}$ : Perceived value do not have significant effect on usage of online retailing services

As shown in Table 2, for perceived value, $\beta=2.340$ and $p$-value $=0.023$. Therefore, the null hypothesis was rejected since $\beta \neq 0$ and $p$-value $<$. This means that perceived value has a statistically significant effect on the usage of online retailing services. The findings of the study are consistent with the previous research which established that perceived customer value is a significant determinant of online transaction behavior (Chew, Shingi \& Ahmad, 2006). As pointed out by Abadi, Hafshejani and Zadeh (2011), users will perceive online shopping to be valuable when they see colleagues, friends and family members use it and get a recommendation of using it from them.

\section{Final Considerations}

\subsection{Conclusions}

Three important conclusions can be drawn from the findings of this study. First, the current study has shown that perceived attributes is the most pronounced factor motivating the usage of online retailing services in Kenya. Second, the results have drawn attention to the role of perceived risk as a barrier to online retailing usage in Kenya. It is evident from the study that perceived risk plays a key role in determining continued usage of online retailing services, albeit a negative one. Third, the study conclusively established that perceived value is positively associated with usage of online retailing services. 


\subsection{Implications of the study}

The empirical findings of this study have implications for scholars, practitioners as well as policy makers.

\subsubsection{Theoretical implications of the study}

Four widely-used IS and consumer behavior constructs were empirically tested. The findings demonstrate that the proposed study model can explain a significant amount of variance in usage of electronic retailing services. The research model shows that online retailing use by consumers depends on their perceptions vis-à-vis the website attributes, risk and value satisfaction, confirming that e-consumer behaviour depends on individual perceptions. This study therefore makes an important theoretical contribution to explaining online consumer behavior.

\subsubsection{Practical implications of the study}

For practitioners, the study recommends that online retailers should above all enhance service features/attributes as a way of ensuring success of their services by taking into consideration customer-specific needs by personalizing the website to make it more useful, compatible with customer requirements and easy to use for users with various levels of computer skills. Secondly, online retailing service providers need to build trust amongst their users regarding online purchasing as a way of increasing their willingness to continue using their service. Third, online retailers should design and deliver a unique value proposition that has both functional as well as hedonistic appeals. In short, it is imperative for online retailing firms to have a good understanding of their target customers, since this will not only help in determining the appropriate customer engagement strategies but also how to enhance the long-term usage of their services.

\subsubsection{Policy implications of the study}

Last but not least, the study recommends that the government should address some of the barriers to online retailing usage primarily through policy. Also, the government could license a suitable entity to oversee online consumer protection. Further, government ICT entities should engage various stakeholders with a view of promoting usage of online retailing services.

\section{Acknowledgement}

This research is part of a PhD thesis submitted to the School of Business, Kenyatta University, Kenya.

\section{References}

Abadi, H.R.D., Hafshejani, S.N.A., \& Zadeh, F.K. (2011). Considering factors that affect users' online purchase intentions with using structural equation modeling. Interdisciplinary Journal of Contemporary Research in Business, 3(8), 463-471. 
Adams, D.A., Nelson, R.R., \& Todd, P.A. (1992). Perceived usefulness, ease-of-use and usage of information technology: A replication. MIS Quarterly, 16(2), 227-247. http://dx.doi.org/10.2307/249577

Alba, J., Lynch, J., Weitz, B., \& Janisqewski, C. (1997). Interactive home shopping: Consumer, retailer, and manufacturer incentives to participate in electronic marketplaces. Journal of Marketing, 61(3), 38-53. http://dx.doi.org/10.2307/1251788

Al-Gahtani, S. (2001). The applicability of TAM outside North America: An empirical test in the United Kingdom. Information Resources Management Journal, 14(3), 37-46. http://dx.doi.org/10.4018/irmj.2001070104

Anderson, L. (2000, March). Retail and wholesale industry. Hoover's Online. Retrieved from www.hooversonline.com.

Barnes, S.J., Bauer, H.H., Neumann, M.M., \& Huber, F. (2007). Segmenting cyberspace: A customer typology for the internet. European Journal of Marketing, 41(1/2), 71-93. http://dx.doi.org/10.1108/03090560710718120

Bauer, R.A. (1960). Consumer behavior as risk-taking. In R.S. Hancock (Ed.). Dynamic Marketing for a Changing World (pp. 389-98). Chicago, IL: American Marketing Association.

Bettman, J. (1973). Perceived risk and its components - A model and empirical test. Journal of Marketing Research, 10, 184-90. http://dx.doi.org/10.2307/3149824

Bhatnagar, A., Misra, S., \& Rao, H. R. (2000). Online risk, convenience and internet shopping behavior. Communications of the ACM, 42(11), 98-105. http://dx.doi.org/10.1145/353360.353371

Bhattacherjee, A. (2001a). Understanding information systems continuance: An expectation-confirmation model. MIS Quarterly, 25(3), 351-70. http://dx.doi.org/10.2307/3250921

Bhattacherjee, A. (2001b). An empirical analysis of the antecedents of electronic commerce service continuance. Decision Support Systems, 32(2), 201-214. http://dx.doi.org/10.1016/S0167-9236(01)00111-7

Bhattacherjee, A., \& Barfar, A. (2011), Information technology continuance research: Current state and future directions. Asia Pacific Journal of Information Systems, 21(2), 1-18.

Bhatnagar, A., Misra, S., \& Rao, H. R. (2000). Online risk, convenience and internet shopping behavior. Communications of the ACM, 42(11), 98-105. http://dx.doi.org/10.1145/353360.353371

Boscheck, R. (1998). New media economics are transforming consumer relations. Long Range Planning, 31, 873-878. http://dx.doi.org/10.1016/S0024-6301(98)80023-X

Bridges, E., \& Florsheim, R. (2008). Hedonic and utilitarian shopping goals: The online experience. Journal of Business Research, 61(4), 309-314. http://dx.doi.org/10.1016/j.jbusres.2007.06.017 
Burns, R. P., \& Burns, R. (2009). Business Research Methods and Statistics Using SPSS, London: Sage Publications.

CCK. (2012). CCK Statistics Report on the Communication Sector Q4 2011/2012. Retrieved from www.cck.go.ke.

Chan, Y. H. (2004). Biostatistics 202: Logistics regression analysis, Singapore Medical Journal, 45(4), 149-153.

Chen, L.D., Gillenson, M.L., \& Sherrell, D.L. (2002). Enticing online consumers: An extended technology acceptance perspective. Information \& Management, 39, 705-719. http://dx.doi.org/10.1016/S0378-7206(01)00127-6

Chen, Z. and Dubinsky, A.J. (2003). A conceptual model of perceived customer value in e-Commerce: A preliminary investigation. Psychology \& Marketing, 20(4), 323-347. http://dx.doi.org/10.1002/mar.10076

Chen, Q. \& Wells, W.D. (1999). Attitude toward the site, Journal of Advertising Research, September/October, pp. 27-37.

Chew, K.-W., Shingi, P. M., \& Ahmad, M.I. (2006). TAM derived construct of perceived customer value and online purchase behavior: An empirical exploration. In R. Suomi, R. Cabral, J.F. Hampe, A. Heikkilä, J. Järveläinen, E. Koskivaara (Eds.). Project E-Society: Building Bricks - 6th IFIP International Conference on e-Commerce, e-Business, and e-Government (13E 2006), October 11-13, 2006, 226, (pp. 215-227). IFIP Advances in Information and Communication Technology.

Chircu, A.M., \& Kauffman, R.J. (2000). Limits to value in electronic commerce-related IT investments. Journal of Management Information Systems, 17(2), 59-80.

Choi, J.H. \& Jahng, J.J. (2009). Predictors of E-commerce Use of the Internet: A Multinational Comparative Study - the U.S., the Netherlands, and S. Korea. Seoul Journal of Business, 15(1), $65-90$.

Cooper, R. B. \& Zmud, R.W. (1990). Information Technology Implementation Research: A Technological Diffusion Approach. Management Science, 36(2), 123-139. http://dx.doi.org/10.1287/mnsc.36.2.123

Cox, D.F., \& Rich, S.U. (1964). Perceived risk and consumer decision making - the case of telephone shopping. Journal of Marketing Research, 1, 2-39. http://dx.doi.org/10.2307/3150375

Cunningham, S. M. (1967), The major dimensions of perceived risk. In D. Cox (Ed.), Risk taking and information handling in consumer behavior (pp. 82-109). Harvard: Harvard University Press.

Daniel, E. \& Klimis, G.M. (1999). The impact of electronic commerce on market structure: An evaluation of the electronic market hypothesis. European Management Journal, 17(3), 318-325. http://dx.doi.org/10.1016/S0263-2373(99)00011-0 
Davis, F.D. (1989). Perceived usefulness, perceived ease of use, and user acceptance of information technology. MIS Quarterly, 13(3), 319-340. http://dx.doi.org/10.2307/249008

Dholakia, R. \& Uusitalo, O. (2002). Switching to electronic stores: Consumer characteristics and the perception of shopping benefits. International Journal of Retail and Distribution Management, 27(4), 154-165. http://dx.doi.org/10.1108/09590559910268499

Doherty, N. F., \& Ellis-Chadwick, F. (2010). Internet retailing: The past, the present and the future. International Journal of Retail \& Distribution Management, 38(11/12), 943-965. http://dx.doi.org/10.1108/09590551011086000

Doll, W. and Torkzadeh, G. (1998). Developing a multidimensional measure of system-use in an organizational context, Information \& Management, 33, 171-185. http://dx.doi.org/10.1016/S0378-7206(98)00028-7

El-Kasheir, D., Ashour, A.S., \& Yacout, O.M. (2009). Factors affecting continued usage of internet banking among Egyptian customers. Communications of the IBIMA, 9, 252-263. ISSN: 1943-7765.

Fichman, R.G., \& Kemerer, C.F. (1999). The illusory diffusion of innovation: An examination of assimilation gaps. Information Systems Research, 10(3), 255-275. http://dx.doi.org/10.1287/isre.10.3.255

Forsythe, S., Chuanlan, N., Shannon, D., \& Gardner, L.C. (2006), Development of a scale to measure the perceived benefits and risks of online shopping, Journal of Interactive Marketing, 20 ( 2), 55 - 75. http://dx.doi.org/10.1002/dir.20061

Gimpel, G. (2011). Value-driven adoption and consumption of technology: Understanding Technology Decision Making. Unpublished Phd Thesis. Retrieved fromhttp://openarchive.cbs.dk/bitstream/handle/10398/8326/Gregory\%20Gimpel.pdf?sequen $\mathrm{ce}=1$ (accessed on August, 2012).

Hansen, T. (2005). Consumer adoption of online grocery buying: A discriminant analysis. International Journal of Retail \& Distribution Management, 33(2), 101-121. http://dx.doi.org/10.1108/09590550510581449

Hansen, T. (2007). Determinants of consumers' repeat online buying of groceries. The International Review of Retail, Distribution and Consumer Research, 16(1), 93-114. http://dx.doi.org/10.1080/09593960500453617

Hong, S., Thong, J.Y.L., \& Tam, K.Y. (2006). Understanding continued information technology usage behavior: A comparison of three models in the context of mobile internet, Decision Support Systems, 42, 1819-1834. http://dx.doi.org/10.1016/j.dss.2006.03.009

Hu, F-L., \& Chuang, C.C. (2012). A study of the relationship between the value perception and loyalty intention toward an e-retailer website. Journal of Internet Banking and Commerce, 17(1), 1-18.

Huang, E. (2008). Use and gratification in e-consumers. Internet Research, 18(4), 405-426. http://dx.doi.org/10.1108/10662240810897817 
Jarvenpaa, S.L., \& Todd, P. A. (1996). Consumer reactions to electronic shopping on the world wide web. International Journal of Electronic Commerce, 1(2), 59-88.

Jarvenpaa, S.L., \& Tractinsky, N. (1999). Consumer trust in an internet store: a cross-cultural validation. Journal of Computer-Mediated Communication, 5(2).

Jacoby, J., \& Kaplan, L. (1972). The components of perceived risk. In M. Venkatesan (Ed.), Proceedings, 3rd Annual Conference (pp. 383 - 393). Chicago, IL: Association for Consumer Research.

Joines, J.L., Scherer, C.W., \& Scheufele, D.A. (2003). Exploring motivations for consumer web use and their implications for e-commerce, Journal of Consumer Marketing, 20(2), 90-108. http://dx.doi.org/10.1108/07363760310464578

Kalafatis, S., Ledden, L. \& Mathioudakis, A. (2010). Re-Specification Of The Theory Of Consumption Values. Emerging Issues in Business and Law. Kingston Upon Thames, U.K.(Unpublished).

Kau, A.K., Tang, Y.E. \& Ghose, S. (2003). Typology of online shoppers. Journal of Consumer Marketing, 20(2/3), 139-154. http://dx.doi.org/10.1108/07363760310464604

Kaye, B.K. \& Johnson, T.J. (2001). A Web for all reasons: uses and gratifications of Internet resources for political information, paper presented at the Association for Education in Journalism and Mass Communication Annual Conference, Washington, DC, August.

Kim, H., Lee, I., \& Kim, J. (2008). Maintaining continuers vs. converting discontinuers: relative importance of post-adoption factors for mobile data services. International Journal of Mobile Communications, 6(1), 108-132. http://dx.doi.org/10.1504/IJMC.2008.016007

Ko, H., Cho, C-H., \& Roberts, M.S. (2005). Internet uses and gratifications. Journal of Advertising, 34(2), 57-70. http://dx.doi.org/10.1080/00913367.2005.10639191

Korgaonkar, P.K., \& Wolin, L.D. (1999). A multivariate analysis of Web usage, Journal of Advertising Research, 39(2), 53-68.

Lee, D., Park, J., \& Ahn, J. (2000). On the explanation of factors affecting e-commerce adoption, Working Paper. Retrieved from http://misrc.umn.edu/workingpapers/fullpapers/2000/0025_120100.pdf

Liebermann, Y., \& Stashevsky, S. (2002). Perceived risks as barriers to internet and e-commerce usage. Qualitative Market Research: An International Journal, 5(4), 291-300. http://dx.doi.org/10.1108/13522750210443245

Limayem, M., Hirt, S.G., \& Cheung, C.M.K. (2007). How habit limits the predictive power of intention: The case of information systems continuance. MIS Quarterly, 31(4), 705-37.

Liou, F-M. (2008). Fraudulent financial reporting detection and business failure prediction models: A comparison. Managerial Auditing Journal, 23(7), 660-662. http://dx.doi.org/10.1108/02686900810890625 
Liu, C., \& Forsythe, S. (2010). Post-adoption online shopping continuance. International Journal of Retail \& Distribution Management, 38(2), 97-114. http://dx.doi.org/10.1108/09590551011020110

Luo, X. (2002). Uses and gratifications theory and e-consumer behaviors: a structural equation modeling study. Journal of Interactive Advertising, 2(2).

Magutu, P.O., Mwangi, M., Nyaoga, R.B., Ondimu, G.M., Kagu, M., Mutai, K., Kilonzo, H., \& Nthenya, P. (2011). E-Commerce products and services in the banking industry: The adoption and usage in commercial banks in Kenya, Journal of Electronic Banking Systems, $1-19$.

McGuire, W.J. (1974). Psychological motives and communication gratification, in Blumler, J.G. and Katz, E. (Eds), The Uses of Mass Communication, Sage, Beverly Hills, CA.

Monsuwé, T.P., Dellaert, B.G.C., \& De Ruyter, K. (2004), What drives consumers to shop online: A literature review. International Journal of Service Industry Management, 15(1), 102-121. http://dx.doi.org/10.1108/09564230410523358

Moore, G. C., \& Benbasat, I. (1991). Development of an instrument to measure the perceptions of adopting an information technology innovation. Information Systems Res., 2, 192-222. http://dx.doi.org/10.1287/isre.2.3.192

Murray, C. (2009). Diffusion of innovation theory: A bridge for the research-practice gap in counseling", Journal of Counseling \& Development, 87(1), 108-16. http://dx.doi.org/10.1002/j.1556-6678.2009.tb00556.x

Ozen, H., \& Kodas, N. (2011). Utilitarian or hedonic? A Cross cultural study in online shopping, Organizations and Markets in Emerging Economies, 3(2), 80 - 90.

Pallant, J. (2007). SPSS Survival Manual ( $3^{\text {rd }}$ Edition). Crows West: New South Wales.

Parthasarathy, M., \& Bhattacherjee, A. (1998). Understanding post-adoption behavior in the context of online services. Information Systems Research, 9, 362. http://dx.doi.org/10.1287/isre.9.4.362

Peng, D. W-J. (2007). Factors affecting consumers' uses and gratifications of the Internet: A cross-cultural comparison among Taiwan, Hong Kong and China. International Journal of Computer Sciences and Network Security, 7(3), 233-242.

Rayburn, J.D. (1996). Uses and gratifications, in Salwen, M.B. and Stacks, D.W. (Eds), An Integrated Approach to Communication Theory and Research, Lawrence Erlbaum, Mahwah, NJ, pp. 145-63.

Rogers, E.M. (1962). Diffusion of Innovations. The Free Press.

Rogers, E.M. (1995). Diffusion of Innovations, $\left(4^{\text {th }}\right.$ Ed.). New York: The Free Press.

Rogers, E.M. (2003). Diffusion of Innovations ( $5^{\text {th }}$ Ed.). New York: The Free Press. 
Roy, S.K. (2008). Determining Uses and Gratifications for Indian Internet Users. CS-BIGS 2(2): 78-91. Retrieved from http://www.bentley.edu/centers/sites/www.bentley.edu.centers/files/csbigs/roy.pdf

Rubin, A. \& Babbie, E. R. (2011), Research Methods for Social Work ( $7^{\text {th }}$ Ed). Belmonst, CA: Cengage Learning.

Rugimbana, R. \& Iversen, P. (1994). Perceived Attributes of ATMs and their Marketing Implications. International Journal of Bank Marketing, 12(2), 0-35. http://dx.doi.org/10.1108/02652329410052955

Saeed, K., \& Abdinnour-Helm, S. (2008). Examining the effects of information system characteristics and perceived usefulness on post adoption usage of information systems. Information and Management, 45(6), 376-386. http://dx.doi.org/10.1016/j.im.2008.06.002

Severin, W. J., \& Taknard, W. J. (1997). Communication Theories Origins, Methods, and Uses in the Mass Media (4th ed.), White Plains, NY: Longman.

Sharma, S., Durand, R.M., \& Gurarie, O. (1981). Identification and Analysis of Moderator Variables, Journal of Marketing Research, 18(3), 45-57. http://dx.doi.org/10.2307/3150970

Sheth, J.N., Newman, B.I., \& Gross, B.L. (1991a). Consumption values and market choices: Theory and applications. Cincinnati: South-Western Publishing Co.

Sheth, J.N., Newman, B.I., \& Gross, B.L. (1991b). Why we buy what we buy: A theory of consumption values. Journal of Business Research, 22(2), 159-170. http://dx.doi.org/10.1016/0148-2963(91)90050-8

Shih, C.-F., \& Venkatesh, A. (2004). Beyond adoption: Development and application of a use-diffusion model. Journal of Marketing, 68(1), 59-72. http://dx.doi.org/10.1509/jmkg.68.1.59.24029

Smith, T. J. (2008). Senior citizens and e-commerce websites: The role of perceived usefulness, perceived ease of use, and website usability. Informing Science: the International Journal of an Emerging Transdiscipline, 11, 59-83.

Swanson, R.A., \& Holton, E.F.III. (Eds.) (2005). Research in organizations: Foundations and methods of inquiry. San Francisco: Berrett-Koehler.

Taylor, J.W. (1974). The role of risk in consumer behavior. Journal of Marketing, 38(2), 54-60. http://dx.doi.org/10.2307/1250198

Tornatzky, L.G., \& Klein (1982). Innovation characteristics and innovation adoption implementation: A meta-analysis of findings. IEEE Transaction on Engineering Management, 29(1), 28-43. http://dx.doi.org/10.1109/TEM.1982.6447463

Verhoef, P.C., \& Langerak, F. (2001). Possible determinants of consumers' adoption of electronic grocery shopping in the Netherlands. Journal of Retailing and Consumer Services, 8, 275-285. http://dx.doi.org/10.1016/S0969-6989(00)00033-3 
Vrechopoulos, A., Siomkos, G., \& Doukidis, G. (2001). Internet shopping adoption by Greek Consumers. European Journal of Innovation Management, 4(3), 142-152. http://dx.doi.org/10.1108/14601060110399306

Weltevrenden, J. W. J., \& Boschma, R.A. (2008). Internet strategies and the performance of Dutch retailers. Journal of Retailing \& Consumer Services, 15, 163-178. http://dx.doi.org/10.1016/j.jretconser.2007.06.006

Wilson, A. (2006). Marketing research: An integrated approach. ( $2^{\text {nd }}$ Ed.). Gosport: Prentice Hall.

Yen, Y.S. (2011). The impact of perceived value on continued usage intention in social networki4ng sites. Proceedings of the 2nd International Conference on Networking and Information Technology, 17, 217-223.

yStats.com (2012). Africa internet \& b2c e-commerce report 2012, Hamburg: yStats.com Gmbh. \& Co. KG.

Yunjie, X., \& Shun, C. (2004). A conceptual model for customer value in e-commerce. Retrieved from http://is2.1se.ac.uk/asp/aspecis/20040178.pdf.

Zhang, L., Tan, W., Xu, Y., \& Tan, G. (2012), Dimensions of consumers' perceived risk and their influences on online consumers' purchasing behavior. Communications in Information Science and Management Engineering, 2(7), 8-14.

Zhou, Lina, Liwei Dai, \& Dongsong Zhang (2007). Online shopping acceptance model: A critical survey of consumer factors in online shopping. Journal of Electronic Commerce Research, 8(1), 41-62.

\section{Appendix}

Appendix 1. Survey Questions for Customer Perception Measures

Please indicate the extent to which you disagree or agree with each of the following statements by marking with a cross $(\mathrm{X})$ in the appropriate block provided. Please use the following seven-point rating scale ranging from $1=$ "strongly disagree" to 7 = "strongly agree"

\begin{tabular}{|l|l|l|l|l|l|l|l|l|}
\hline \multicolumn{1}{|c|}{ CUSTOMER PERCEPTIONS } & \multicolumn{5}{c|}{ Value Label } \\
\hline & \multicolumn{1}{|c|}{ Variable Label } & \multicolumn{1}{|c|}{ Perceived Attributes } & $\mathbf{2}$ & $\mathbf{3}$ & $\mathbf{4}$ & $\mathbf{5}$ & $\mathbf{6}$ & $\mathbf{7}$ \\
\hline & \multicolumn{1}{|c|}{$\begin{array}{l}\text { The system enables me to accomplish what I want more } \\
\text { quickly }\end{array}$} & & & & & & \\
\hline 2. & The system makes me more effective & & & & & & \\
\hline 3. & The system makes it easier to do what I want & & & & & & & \\
\hline 4. & I find the system useful & & & & & & & \\
\hline 5. & The e-commerce service fits my image well. & & & & & \\
\hline 6. & Using the system is compatible with all aspects of my & & & & & & \\
\hline
\end{tabular}




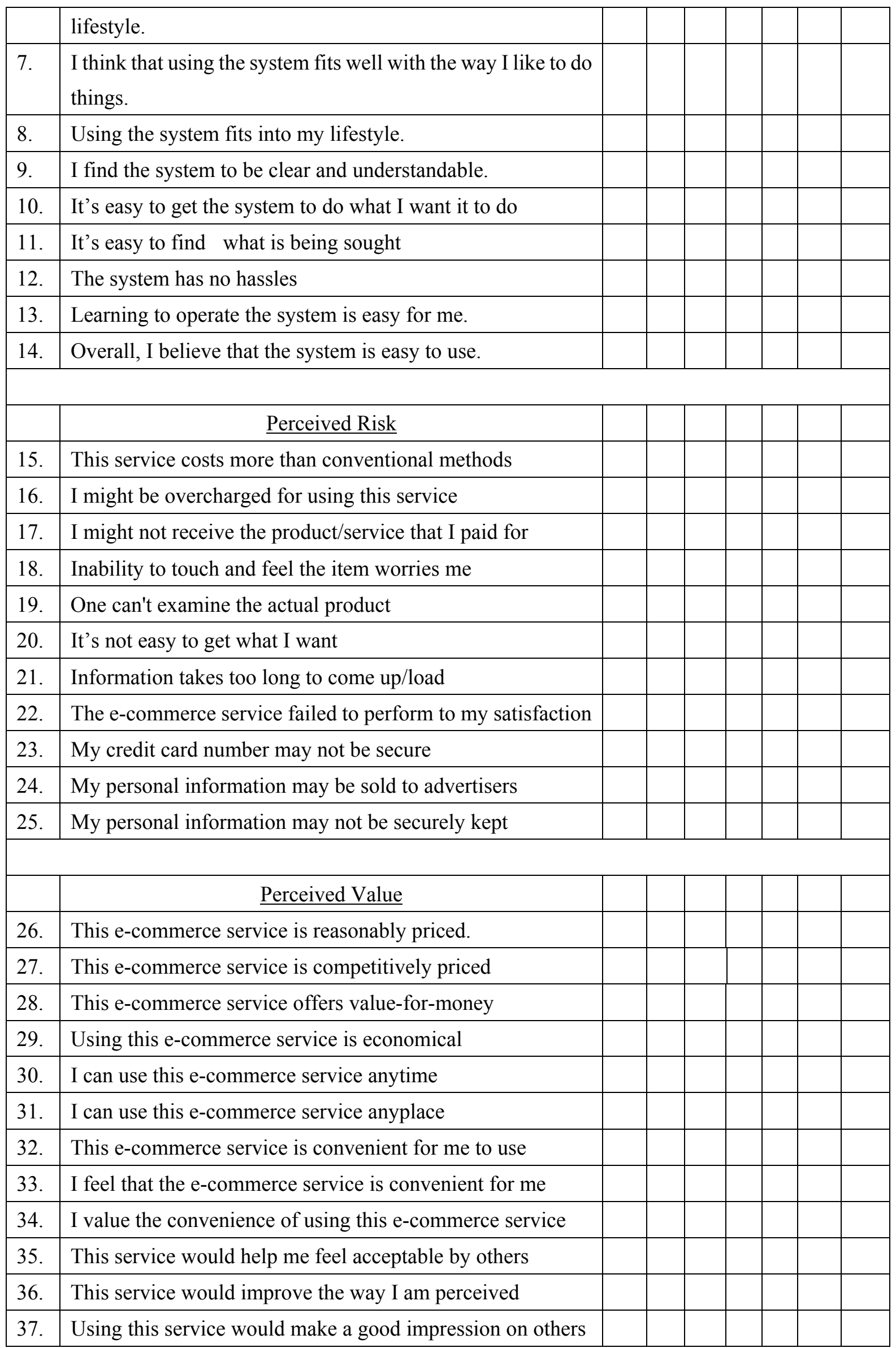




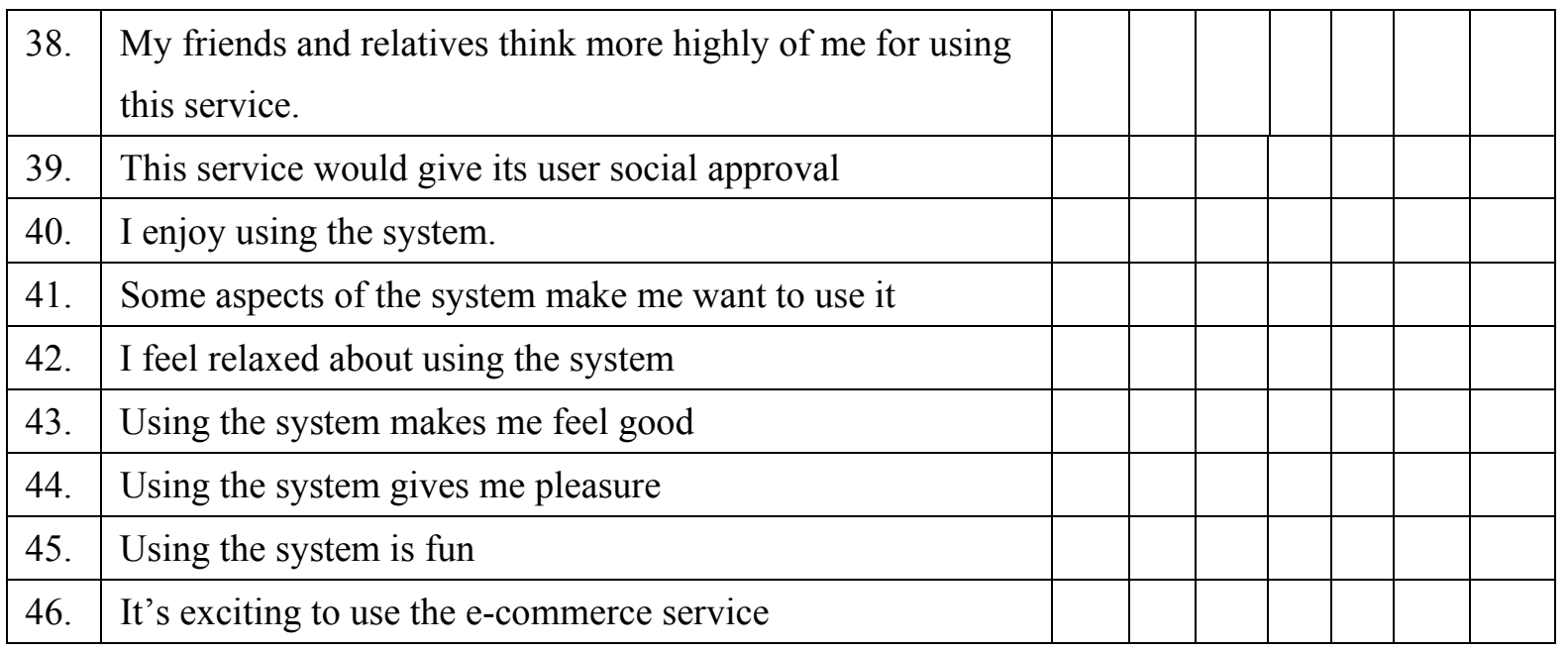

Appendix 2. Conceptual Framework for the Study

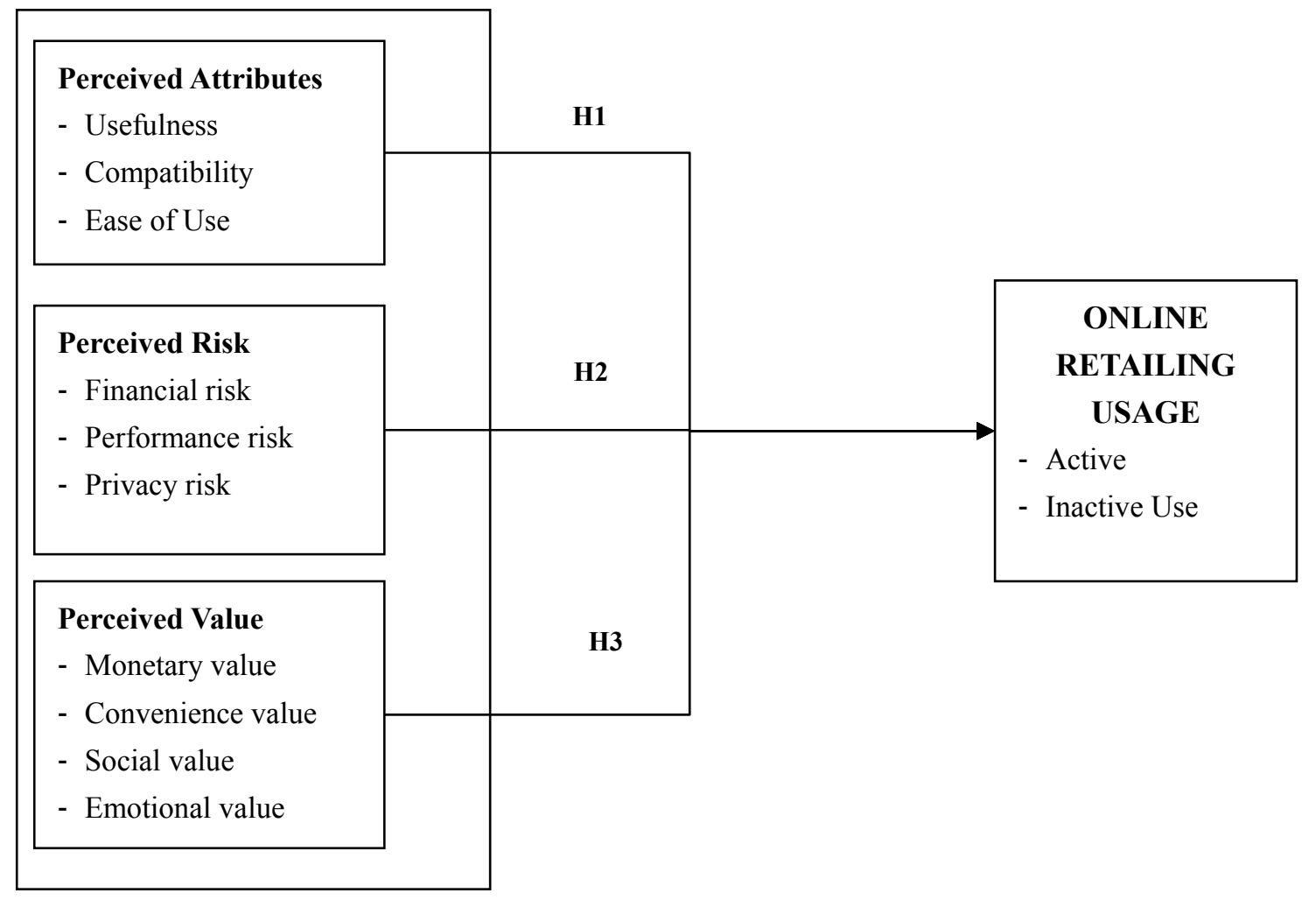

Figure 1. Conceptual Model

Source: Author (2014).

\section{Copyright Disclaimer}

Copyright reserved by the author(s).

This article is an open-access article distributed under the terms and conditions of the Creative Commons Attribution license (http://creativecommons.org/licenses/by/3.0/). 